\title{
Calvin dan Potensi Pemikirannya bagi Ibadah Kristen
}

\section{Calvin and the Potential of His Thought for Christian Worship}

\author{
Billy Kristanto \\ Sekolah Tinggi Teologi Reformed Injili Internasional \\ bkrstn@yahoo.com
}

\begin{abstract}
Abstrak: Dalam artikel ini disajikan potensi beberapa pemikiran Yohanes Calvin bagi ibadah Kristen masa kini maupun masa yang akan datang. Ibadah menurut Calvin sepertinya tidak menjanjikan untuk dikembangkan dalam konteks masa kini karena seringkali dianggap terlalu sempit. Artikel ini berusaha untuk menyajikan perspektif sebaliknya tanpa bermaksud menampilkan superioritas pemikiran Calvin tentang ibadah. Artikel ini mau membagikan kontribusi pemikiran Calvin yang dapat menjadi tuntunan dan koreksi bagi ibadah masa kini. Untuk itu penulis akan membahas prinsip-prinsip teologi reformatoris Calvin yang diaplikasikan dalam aspek ibadah, pandangan Calvin tentang dosa-dosa liturgis, dan gambaran-gambaran atau metafora-metafora yang digunakan Calvin untuk menjelaskan ibadah. Secara metodologis, artikel ini berusaha untuk menimba dan mengontekstualisasikan pikiran Calvin tentang ibadah, namun tidak memberikan pembahasan yang komprehensif dan historis secara ketat. Pemikiran-pemikiran Calvin tentang ibadah bukan saja melampaui pokok bahasan seputar penggunaan alat musik dan Mazmur, melainkan juga memiliki potensi yang kaya untuk pengembangan ibadah Kristen masa kini.
\end{abstract}

Kata-kata kunci: Prinsip-prinsip Dasar Reformatoris, Dosa-dosa Liturgis, Metafora Ibadah, Perjamuan Kudus, Ibadah Reformatoris

Abstract: This article presents the potential of some of John Calvin's thoughts on Christian worship for today and the future. Worship according to Calvin does not seem promising to be developed in the present context because it is often considered too narrow. This article seeks to present a contrary perspective without intending to show the superiority of Calvin's thought about worship. This article would like to share the contribution of Calvin's thought that can serve as a guide and correction for contemporary worship. For this reason, I will discuss the principles of Calvin's theology, which are applied in aspects of worship, Calvin's view of the so-called liturgical sins, and metaphors used by Calvin to explain worship. Methodologically, this article seeks to draw from and contextualize Calvin's thoughts on worship, but does not offer comprehensive and historical discussion in the strict sense. Calvin's thoughts on worship not only goes beyond the subject of the use of musical instruments and psalms, but also has a rich potential for the development of Christian worship for today.

Keywords: Basic Principles of Reformation, Liturgical Sins, Worship Metaphor, Lord's Supper, Reformed Worship 


\section{PENDAHULUAN}

Calvin tidak menuliskan pemikiran yang sistematik dan komprehensif mengenai ibadah. Istilah dalam bahasa Latin yang sering dipakai untuk ibadah adalah pietas dan caritas. $^{1}$ Mengaitkan ibadah dengan nama Yohanes Calvin sering kali menimbulkan konotasi yang negatif. Konotasi negatif ini mencakup kekakuan, larangan-larangan sebagaimana diajarkan dalam prinsip regulatif ibadah (regulative principle of worship), termasuk pandangan Calvin sendiri tentang penggunaan alat-alat musik dalam ibadah, dan juga penggunaan Mazmur secara eksklusif. ${ }^{2}$ Gambaran seperti ini, sekalipun ada benarnya, sesungguhnya merupakan gambaran yang sangat parsial dari pemahaman Calvin tentang ibadah. Ada banyak hal-hal lain yang bisa digali dalam pemikiran Calvin. Prinsipprinsip dasar Calvin tentang ibadah memiliki aplikasi bagi ibadah masa kini. Dalam artikelnya tentang liturgi Calvin, Witvliet dan Bierma menjelaskan bahwa Calvin berkhotbah melawan dosa-dosa liturgis dan menggunakan metafora-metafora untuk menjelaskan ibadah. ${ }^{3}$ Calvin mengidentifikasi beberapa dosa liturgis, yaitu ketidaktaatan, kemunafikan, takhayul, dan pemberhalaan sebagaimana dikemukakan oleh Witvliet, yang menelusuri pemikiran Calvin mengenai ibadah. Dengan bertitik tolak dari kerangka Witvliet, artikel ini akan mengeksplorasi lebih lanjut

${ }^{1}$ Bdk. Elsie Anne McKee, "Context, Contours, Contents: Towards a Description of the Classical Reformed Teaching on Worship," Princeton Seminary Bulletin 16 (1995): 173, 181

${ }^{2}$ Lih. John Frame, "Some Questions about the Regulative Principle," Westminster Theological Journal 54, no. 2 (1992): 357-66; Brian M. Schwertley, Stephen Pribble \& John Frame, Sola scriptura and the regulative principle of worship (Southfield: Reformed Witness, 2000). Lih. juga Jeremy Begbie, Music, Modernity, and God (Oxford: Oxford University Press, 2014), 10-40.

${ }^{3}$ Bdk. John D. Witvliet \& Nathan Bierma, "Liturgy," dalam The Calvin Handbook, diedit oleh Herman J. Selderhuis (Grand Rapids: Eerdmans, 2009), 417. Lih. juga John D. Witvliet, Worship Seeking Understanding: Windows into Christian Practice (Grand Rapids: Baker Academic, 2003), 127-148. pemahaman Calvin tentang ibadah dari tulisan-tulisannya sendiri, dan kemudian menggali potensinya bagi ibadah masa kini. Setiap bagian akan dimulai dengan apa yang diajarkan oleh Calvin dan disusul dengan potensi pemikirannya bagi ibadah masa kini.

Berangkat dari pemahaman Witvliet dan Bierma, dapat dilihat bahwa Calvin tidak memberikan definisi proposisional tentang apa itu ibadah. Penjelasannya tentang ibadah bukanlah sebuah pemahaman ontologis melainkan penggambaran metaforis. Tidak cukup hanya dengan satu atau dua metafora, Calvin menyuguhkan berbagai metafora tentang ibadah. Seolah melampaui zaman modern, gambaran metaforis tentang ibadah ini memiliki potensi relevansi bagi ibadah masa kini yang lebih banyak diwarnai dengan gambar-gambar daripada konsep-konsep definitif dan proposisional. Gambar multifaset yang disajikan oleh Calvin ini memiliki potensi untuk memperkaya ibadah masa kini yang seringkali memiliki kecenderungan berat sebelah dengan penekanan atas satu sampai dua aspek saja. Ibadah Kristen yang multifaset atau multigambar ini dapat menolong ibadah yang monoton di satu sisi dan juga keragaman yang tidak terintegrasi di sisi yang lain. Calvin hanya menimba gambarangambaran tentang ibadah ini dari Kitab Suci. Calvin memang bukanlah seorang teolog yang kreatif, seperti dikatakan oleh Wilhelm Dilthey, ${ }^{4}$ namun setidaknya dia dapat membawa kita kepada kekayaan dan keindahan firman Tuhan.

\section{PRINSIP-PRINSIP IBADAH}

Prinsip pertama yang memiliki potensial untuk ibadah masa kini adalah prinsip reformasi total. Secara negatif, reformasi total tidak identik dengan solus sermo (khotbah saja). Berbeda dengan Luther yang sangat

${ }^{4}$ Kalimat yang diucapkannya adalah "Ein denkmächtiger aber unschöpferischer Kopf." Lihat Wilhelm Dilthey, Die Glaubenslehre der Reformatoren (Preuss. Jahrb. 1894), 74 
percaya pada kuasa khotbah ketika dia berbicara tentang reformasi, ${ }^{5}$ Calvin di akhir hidupnya mengenang apa yang ada ketika dia datang ke Jenewa yaitu bahwa pada saat itu yang ada hanya khotbah dan belum ada reformasi. ${ }^{6}$ Ini berarti bahwa bagi Calvin, reformasi bukan hanya soal khotbah melainkan juga soal bagaimana penduduk kota Jenewa merancang gaya hidup mereka sesuai dengan iman reformatoris. ${ }^{7}$ Dalam konteks ibadah yang sejati, adalah penting untuk menyadari bahwa tidak seorang pun yang sempurna. Calvin mencatat beberapa kerusakan di zamannya:

Some are cold; others, negligent of the public good, give their whole attention to their own affairs; others indulge their own private affections; others use not the excellent gifts of God as is meet; others ostentatiously display themselves, and, from overweening confidence, insist that all their opinions shall be approved by others. ${ }^{8}$

Reformasi total harus membenahi kesalahan di atas. Ini berarti bagi Calvin ibadah yang sejati tidak berhenti pada hari Minggu, melainkan bagaimana kesalehan yang sejati itu mengubah kehidupan orang percaya secara

${ }^{5}$ Luther mengatakan, "I simply taught, preached, and wrote God's Word; otherwise I did nothing. And while I slept ... the Word so greatly weakened the papacy that no prince or emperor ever inflicted such losses upon it" (penekanan oleh penulis). Lihat Martin Luther, "Invocavit Sermon 2 (March 1522)," dalam Documents from the History of Lutheranism, 1517-1750, terj. John Doberstein, ed. Eric Lund (Minneapolis: Fortress, 2002), 38.

${ }^{6}$ Calvin mengatakan, "When I first came to this church, I found almost nothing in it. There was preaching and that was all. ... there was no reformation." Lih. John Calvin, Selections from His Writings, ed. J. Dillenberger (Garden City: Doubleday, 1971), 41, yang dikutip dari B. A. Gerrish, The Old Protestantism and the New (Chicago: University of Chicago Press, 1982), 258. Gerrish membandingkan Luther dengan Calvin dan menggambarkan bahwa bagi Calvin, khotbah saja bukan berarti reformasi.

${ }^{7}$ Bdk. Michel Grandjean, "Genf: Johannes Calvin und Theodor Beza," dalam Europa Reformata: Reformationsstädte Europas und ihre Reformatoren, ed. Michael Welker, Michael Beintker dan Albert de Lange (Leipzig: Evangelische Verlagsanstalt, 2016), 149-154.

${ }^{8}$ Calvin, Selections from His Writings, 39-40. menyeluruh. Dalam sebuah pengumuman publik tahun 1549 tentang ibadah, moral, dan tingkah laku terdapat peringatan keras terhadap penghujatan nama Tuhan, kewajiban untuk mendengar firman Allah pada harihari Minggu, untuk mengirimkan anak-anak agar mengikuti katekismus, dan larangan untuk berkeliaran di jalan-jalan atau menongkrong di bar selama waktu khotbah pada hari Minggu. ${ }^{9} \quad$ Dari pengaturan seperti ini kita bisa melihat bahwa Calvin sungguh-sungguh mengusahakan prinsip reformasi total ini dihayati oleh penduduk kota Jenewa. Reformasi yang terintegratif ini berpotensi untuk menjadi koreksi bagi ibadah masa kini, dan juga bagi ibadah kaum Injili, yang cenderung menekankan keberpusatan pada mimbar saja. Sebagai akibatnya, jemaat secara tidak sadar meremehkan pentingnya integrasi kesalehan dalam kehidupan sehari-hari. Akibat buruk yang lain adalah jemaat tidak sungguh-sungguh memahami bahwa pemikiran tentang ibadah seharusnya melampaui konteks ibadah pada hari Minggu. Belajar dari Calvin, jemaat masa kini dapat dididik untuk menghayati kekayaan teologi ibadah bagi keseluruhan aspek kehidupan.

Prinsip yang lain yaitu kesederhanaan. Dalam pemahaman Calvin, kesederhanaan ini penting bukan demi kesederhanaan itu sendiri, melainkan untuk menghindarkan jemaat dari distraksi yang dapat timbul karena dekorasi-dekorasi dan ritual-ritual yang rumit. Kerumitan ritual dalam ibadah dapat mengganggu jemaat berfokus pada kemuliaan Kristus. Calvin mendapat pengaruh pentingnya kesederhanaan dalam ibadah ini dari Martin Bucer selama masa pelayanannya di Strasbourg. ${ }^{10}$ Kesederhanaan merupakan sebuah

${ }^{9}$ Bdk. Karin Maag, Lifting Hearts to the Lord: Worship with John Calvin in Sixteenth-Century Geneva (Grand Rapids: Eerdmans, 2016), 176.

${ }^{10}$ Dalam salah satu tulisannya, Bucer mengingatkan, "The lay people should be taught with the word of God and not with dumb rocks, stones and paintings ...." Lihat Ottoman Frederick Cypris, "Basic Principles: Translation and Commentary of Martin Bucer's Grund Und Ursach, 1524” (Disertasi, Union Theological Seminary, 1971), 204. 
prinsip yang penting jika jemaat hendak diselamatkan dari distraksi-distraksi yang tidak perlu dalam ibadah. Mengikuti Bucer, dalam karyanya Institutio, Calvin juga mengkritik ibadah yang dikemas seperti layaknya sebuah pertunjukan teater yang kehilangan kesederhanaan. ${ }^{11}$ Inilah ciri khas pandangan Calvin tentang ibadah: kejelasan dan kesederhanaan. ${ }^{12}$ Inti dari kesederhanaan adalah untuk membawa jemaat dapat berkonsentrasi memandang Kristus dan kemuliaanNya. Prinsip kesederhanaan ini menjaga keseimbangan kreatif dalam ibadah. Di satu sisi, ibadah memerlukan liturgi yang baik untuk menyaksikan kekayaan Kitab Suci. Di sisi yang lain, ibadah perlu memperhatikan aspek kesederhanaan untuk membawa manusia kepada pemahaman Injil Kristus yang juga sederhana. Prinsip kesederhanaan ini dapat menjadi dorongan dan penghiburan bagi ibadah masa kini bagi gereja yang tidak memiliki banyak dana untuk mengemas ibadah dengan dekorasi-dekorasi yang rumit. Di sisi yang lain, prinsip yang sama juga dapat menjadi pengingat bagi gereja-gereja yang cenderung menaruh investasi pada hal-hal yang sebenarnya tidak esensial dalam ibadah. Dekorasi-dekorasi dan ritual-ritual yang rumit dan dimutlakkan dapat menjadi penghalang banyak orang untuk melihat dan memahami injil Kristus yang sejati.

${ }^{11}$ Calvin mengatakan, "And this should not be fruitless but should indicate to believers with how great modesty, piety, and reverence they ought to treat sacred things. Now, ceremonies, to be exercises of piety, ought to lead us straight to Christ." Lih. John Calvin, Institutes of the Christian Religion, 4.10.29, 2 vol., ed. J.T. McNeill, terj. Ford L. Battles, vol. 1 (Louisville: Westminster John Knox, 2011), 1207.

${ }^{12}$ Tentang "penyembah-penyembah benar" dalam Injil Yohanes 4:23, Calvin mengomentari: "For why should we fear when we hear that God is pleased with this bare and simple worship, which is disdained by the Papists because it is not swollen with a mass of ceremonies? ... And here again it must be observed that truth is not contrasted to falsehood but to the outward addition of the figures; so that it is, as they say, the pure and simple substance of spiritual worship." Tafsiran Calvin ini dikutip dari Karin Maag, Lifting Hearts to the Lord, 124. Lih. juga Hughes Oliphant Old, Worship: Reformed according to Scripture (Louisville: Westminster John Knox, 2002), 74-77.
Prinsip berikutnya adalah bahwa ibadah yang dilakukan oleh orang percaya bukanlah ibadah yang terjadi hanya di bumi, melainkan juga di surga ${ }^{13}$ Konsep ibadah surgawi ini ditunjang oleh ayat-ayat seperti Mazmur 29:12 , yang sebenarnya merupakan pemahaman sentral dari teologi Bait Suci atau teologi Sion dalam Perjanjian Lama. ${ }^{14}$ Dalam tulisan Calvin sendiri, konsep ini khususnya ditekankan dalam pembahasan mengenai Perjamuan Kudus. ${ }^{15}$ Ia mengingatkan orang percaya agar jangan mencari Yesus Kristus di bawah elemen roti dan anggur tanpa mengarahkan hatinya ke surga. ${ }^{16}$ Sebagaimana dengan mata jasmani orang percaya memandang roti dan anggur dan dengan mata rohani memandang tubuh Kristus yang ada di surga, demikian pula dengan mulut jasmani orang percaya memakan roti (dan meminum anggur) dan dengan mulut rohani menerima tubuh dan darah Kristus. Bagi Calvin, dalam Perjamuan

\footnotetext{
${ }^{13}$ Calvin memang mengutamakan elemen sursum corda ini di dalam Perjamuan Kudus, namun prinsip ini bukan orisinil berasal dari Calvin. Konsep orientasi surgawi ini sudah ada sejak zaman gereja mula-mula; bdk. mis. Cyprian, On the Lord's Prayer xxxi (CSEL 3. i. 289; tr. ANF V. 455); Augustine, Gift of Perseverance xiii. 33 (MPL 45. 1013; tr. NPNF V. 538); Sermons ccxxvii (MPL 38. 1100); Psalms, Ps. 132. 13 (MPL 37. 1736; tr. NPNF [Ps. 133] VIII. 619 f.; LF Psalms VI. 121); dikutip dari Calvin, Instit. 4.17.36, diindeks oleh Ford L. Battles, catatan kaki 22.

${ }^{14}$ Salah satu motif penting dalam teologi Bait Suci ini adalah kehadiran Allah yang khusus dalam bait-Nya. Tuhan telah memilih Sion sebagai tempat kediaman-Nya yang kudus (bdk. Mzm. 132:13-14). Bait Suci di Sion adalah tempat, di mana langit dan bumi bersentuhan (bdk. Mzm. 78:68-69; Yes. 6:1), sehingga ketika bangsa Israel beribadah, mereka bukan hanya beribadah di bumi, melainkan juga beribadah di tempat di mana Allah berada, yaitu di surga.

${ }^{15} \mathrm{Bdk}$. John Calvin, Institutes of the Christian Religion (1536; repr., terj. Ford L. Battles, Grand Rapids: Eerdmans, 1995), 103.

${ }^{16}$ Ini yang dikatakan Calvin, "I only wish to note in passing that to enclose Jesus Christ fantastically under the bread and wine, or so to join him to them as to amuse our understanding there instead of looking at him in heaven, is a pernicious fancy." Kalimat ini ditulis John Calvin tahun 1540 dalam traktat yang berjudul "Short Treatise on the Holy Supper of Our Lord and Only Saviour Jesus Christ." Lihat Calvin: Theological Treatises, terj. dan ed. J.K.S. Reid, Library of Christian Classics, vol. 22 (Philadelphia: Westminster Press, 1965), 159.
} 
Kudus orang-orang pilihan diangkat ke surga untuk bersekutu dengan tubuh Kristus yang ada di surga. Bukan hanya itu, jemaat juga beribadah dan bersekutu bersama dengan orang-orang pilihan sepanjang segala tempat. Prinsip ini dapat mengoreksi pemahaman eklesiologis gereja masa kini yang memiliki kecenderungan sektarian dan gagal melihat keindahan kesatuan gereja yang kudus dan am, yang tentunya akan berdampak pada praktik ibadah. Selain itu, ia juga dapat membebaskan gereja dari kesalahan mengacaukan tanda (atau ritual dalam pengertian yang lebih luas) dengan realitas rohani yang ditunjuk oleh tanda tersebut. Prinsip ibadah surgawi ini penting untuk melawan paham naturalisme atau materialisme yang secara tidak sadar bisa menggerogoti ibadah masa kini. Gereja dipanggil untuk mendorong jemaatnya memperhatikan apa yang tidak kelihatan, perkara-perkara yang di atas, dan bukan apa yang kelihatan (bdk. 2Kor. 4:18; Kol. 3:1-2).

Prinsip lain yang penting yaitu pemahaman sikap hormat dan takut akan pada Allah, kasih kepada-Nya dan sukacita dalam Dia. Bagi Calvin, agama atau kesalehan sejati (pietas) adalah sikap hormat yang digabung dengan kasih kepada Allah. ${ }^{17}$ Pemahaman transendensi Allah yang benar selalu disertai dengan pemahaman imanensi, demikian pula sebaliknya. Bagi Calvin, ibadah yang hanya melihat transendensi Allah tanpa imanensi, atau sebaliknya, yang hanya menyaksikan imanensi Allah tanpa transendensi, belumlah mengenal Allah yang benar. Bukan hanya itu, pietas juga tidak dapat dipisahkan dari caritas. Pietas memang mendahului, namun keaslian relasi transenden-imanen ini pada akhirnya harus diuji dengan kasih kepada sesama (caritas).$^{18}$ Aplikasi konsep ini dalam ibadah masa kini adalah pentingnya keseimbangan antara elemen-elemen ibadah yang

${ }^{17}$ Calvin mengatakan, "I call 'piety' that reverence joined with love of God which the knowledge of his benefits induces" (Instit. 1.2.1).

${ }^{18}$ Bdk. McKee, "Context, Contours, Contents," 182. menyaksikan baik transendensi maupun imanensi ilahi. Gereja masa kini memiliki kecenderungan yang satu sisi dalam penekanannya: entah menekankan sikap hormat dan bersamaan dengan itu, transendensi ilahi, atau kasih yang intim dan bersamaan dengan itu, imanensi ilahi. Hal ini dapat menjadi nyata baik dalam khotbah-khotbah yang disampaikan maupun nyanyian-nyanyian jemaat yang dipilih dalam ibadah. Webber pernah mengeluh bahwa baik ibadah tradisional maupun ibadah kontemporer dari gereja masa kini telah kehilangan sesuatu: "The traditional church was missing the sense of a real and vital experience with God. The contemporary movement was missing substance."19 Jauh sebelum Webber mengusulkan gerakan blended worship, Calvin sebenarnya sudah mengingatkan kita tentang apa itu agama atau kesalehan yang sejati, yang konsepnya sangat relevan dengan situasi ibadah masa kini. Selain itu, integrasi pietas dan caritas juga memiliki potensi untuk menggerakkan orangorang percaya untuk keluar dari bahaya dualisme ibadah di hari Minggu dengan kehidupan sehari-hari karena bagi Calvin, tidak ada ibadah yang benar di hadapan Allah tanpa kasih kepada sesama.

\section{DOSA-DOSA DALAM IBADAH}

Pembahasan tentang ibadah tidak akan lengkap tanpa menyertakan pembahasan tentang halangan-halangan dalam ibadah. Seorang yang sangat peka akan dosa, Calvin mengingatkan gereja akan bahaya-bahaya yang perlu diwaspadai seputar ibadah. Menurut Bierma dan Witvliet, Calvin berkhotbah melawan empat dosa liturgis yaitu ketidaktaatan, kemunafikan, takhayul, dan pemberhalaan. ${ }^{20}$ Penulis akan mengembangkan kerangka acuan ini dari berbagai sumber primer tulisan Calvin.

\footnotetext{
${ }^{19}$ Robert Webber, "Blended Worship," in Exploring the Worship Spectrum, ed. Paul A. Basden (Grand Rapids: Zondervan, 2010), 178.

${ }^{20}$ Witvliet \& Bierma, "Liturgy," 417; lih. juga Witvliet, Worship Seeking Understanding, 129-133.
} 
Mengutip Roma 5:19, Calvin mengatakan bahwa ketidaktaatan adalah awal dari kejatuhan manusia ke dalam dosa, yang akhirnya berakibat pada hilangnya rasa takut akan Allah. ${ }^{21}$ Tanpa rasa takut akan Allah, tidak mungkin manusia dapat beribadah dengan benar. Dari sini dapat ditarik kesimpulan bahwa bagi Calvin, tujuan akhir dari ketaatan adalah ibadah itu sendiri (yang disertai dengan rasa takut akan Allah). Tanpa penghayatan tujuan ini, ketaatan yang diajarkan akan sangat mudah bergeser menuju kekakuan legalis yang tidak akan membawa berkat. Dalam tafsirannya atas Roma 5:19, Calvin menegaskan bahwa seseorang hanya dapat beribadah dengan benar kepada Allah ketika ia taat kepada firman-Nya ${ }^{22}$ Bagi Calvin, ini berarti manusia bukan datang kepada Allah dengan kebenaran perbuatannya, melainkan dengan kebenaran Kristus yang sempurna. Kemungkinan untuk beribadah justru bukan dengan membawa dan membanggakan ketaatan diri, melainkan dengan rendah hati memandang pada kesempurnaan ketaatan Kristus. Dalam tafsirannya atas Kitab Mikha, Calvin menulis, "The beginning of worshiping God and glorifying him is to think humbly and modestly of ourselves." ${ }^{3}$ Ibadah yang benar tidak akan membawa jemaat pada pemahaman penilaian diri sebagai orang-orang yang taat, melainkan pada pemahaman pengenalan akan Kristus yang taat kepada Bapa. Pengenalan yang rendah hati ini akan menumbuhkan rasa takut akan Allah yang benar. Potensi dari pemikiran Calvin ini bermanfaat untuk mencegah jemaat masa kini untuk menempatkan diri secara salah sebagai orang yang

\footnotetext{
${ }^{21}$ Bdk. Calvin, Instit. 2.1.4.

${ }^{22}$ Ini yang dikatakan Calvin, "For then only we truly worship him when we follow what he has commanded us, and render obedience to his word." Lihat tafsiran Calvin terhadap Roma 5:19 dalam Calvin's Commentaries: Romans, Ages Software.

${ }^{23}$ Istilah worshiping dalam bahasa Inggris ini adalah terjemahan dari Haroutunian dalam tafsiran Calvin atas Mikha 6:6-8; lih. Calvin: Commentaries, ed. J. Haroutunian dan L.P. Smith (Philadelphia: Westminster Press, 1958), 317.
}

merasa diri benar ketika datang beribadah. Kebenaran diri sendiri ini menghambat jemaat untuk melihat kemuliaan Kristus dalam belas kasihan dan anugerah-Nya yang dinyatakan dalam ibadah, bahkan menghambat jemaat untuk terus mengagumi Injil Kristus. Selain itu, konsep ketaatan yang benar juga dapat membebaskan ibadah masa kini dari kekakuan-kekakuan legalis yang diciptakan dari gereja yang justru merasa diri taat. Yesus menjanjikan kelegaan bagi mereka yang letih lesu dan berbeban berat karena tuntutan Taurat (bdk. Mat. 11:28). ${ }^{24}$ Bentuk-bentuk Taurat baru dalam ibadah dapat menghalangi jemaat untuk menikmati kelegaan dan istirahat sejati yang seharusnya diberikan dalam ibadah dengan pemahaman ketaatan yang benar.

Dosa liturgis yang berikutnya adalah kemunafikan. Calvin menggambarkan orangorang munafik sebagai orang-orang yang berpura-pura taat kepada Allah dengan pengorbanan eksternal mereka yang remeh, sementara di dalam hati, mereka sebenarnya memberontak terhadap Allah. ${ }^{25}$ Sebagai makhluk yang bertubuh dan berdarah, manusia tidak mungkin tidak memiliki aspek kesalehan eksternal. Ini juga bukan yang sedang dipersoalkan oleh Calvin. Yang dikritik sebenarnya adalah divergensi antara yang di luar dan di dalam. Dalam tafsirannya atas Matius 15:7 Calvin menulis,

First, then, it is wicked hypocrisy, when the honor which men render to God is only in

\footnotetext{
${ }^{24}$ Hare mengomentari: "The invitation is issued neither to the work-burdened nor to the sin-burdened but to the lawburdened, upon whose shoulders 'the scribes and the Pharisees' have laid an intolerable load (23:4)." Lihat Douglas R.A. Hare, Matthew, Interpretation: A Bible Commentary for Teaching and Preaching (Louisville: John Knox Press, 1993), 128.

${ }^{25}$ Calvin mengutarakan, "For where they ought to have remained consistently obedient throughout life, they boldly rebel against him in almost all their deeds, and are zealous to placate him merely with a few paltry sacrifices. Where they ought to serve him in sanctity of life and integrity of heart, they trump up frivolous trifles and worthless little observances with which to win his favor" (Instit. 1.4.4.).
} 
outward appearance; for to approach to God with the mouth, and to honor him with the lips, would not be in itself evil, provided that the heart went before. The substance of what our Lord states on this subject is, that, since the worship of God is spiritual, and as nothing pleases him that is not accompanied by the inward sincerity of the heart, they who make holiness to consist in outward display are hypocrites. ${ }^{26}$

Ketulusan batiniah yang keluar dari dalam hati adalah kemutlakan bukan hanya dalam ibadah masa kini, melainkan dalam semua ibadah yang berkenan pada Allah, karena tanpa hal itu, manusia hanya beribadah kepada Allah secara lahiriah. Kemunafikan adalah salah satu batu sandungan bagi banyak orang yang belum percaya. Menurut survei yang dilakukan oleh Barna Group, sekitar $85 \%$ dari kaum milenial tidak pergi ke gereja karena mereka berpendapat bahwa orang Kristen adalah orang yang munafik. ${ }^{27}$ Salah satu pembenahan yang perlu dikerjakan adalah dengan mencegah sikap ibadah lahiriah yang menyuburkan spiritualitas kemunafikan jemaat. Ibadah yang keluar dari dalam hati akan membawa pada pembentukan kerohanian yang jujur. Hal ini mencakup kejujuran dalam menghadapi kelemahankelemahan diri dalam pertolongan dan anugerah Tuhan.

Dosa liturgis yang lainnya adalah takhayul. Dalam bab awal karyanya Institutio, Calvin menjelaskan bahwa takhayul ini merupakan akibat dari kepercayaan diri yang keliru. ${ }^{28}$ Manusia memiliki hasrat yang keliru untuk menjadikan Allah itu bisa dipegang dan diraba. Natur manusia adalah layaknya sebuah

\footnotetext{
${ }^{26}$ Tafsiran Calvin terhadap Matius 15:7 dalam Calvin's Commentaries: The Harmony of the Gospels, Logos Library System.

${ }^{27}$ Bdk. David Kinnaman, "What Millennials Want When They Visit Church," Barna Group, 4 Maret 2015, diakses 23 April 2020, https://www.barna.com/research/ what-millennials-want-when-they-visit-church.

${ }^{28} \mathrm{Bdk}$. Calvin, Instit. 1.4.1.
}

pabrik berhala yang dapat membawa manusia menyembah dengan sikap takhayul. ${ }^{29}$ Calvin menekankan bahwa ibadah yang benar adalah ibadah yang bersifat rohani, yaitu ibadah yang menghampiri Allah yang tidak kelihatan. Ini berarti ibadah yang benar tidak boleh dicemari dengan ritual-ritual takhayul. ${ }^{30}$ Pada zaman Calvin, salah satu ritual takhayul yang akhirnya membawa kepada pemberhalaan adalah praktik venerasi barang-barang keramat yang diperkenalkan oleh gereja. Calvin mengingatkan bahwa sementara Kristus seharusnya dicari dalam firman-Nya dan sakramen-sakramen, dunia justru tertarik dengan pakaian-Nya, kain lampin-Nya, dan sebagainya. ${ }^{31}$ Sekalipun kita tidak berada dalam zaman Calvin dengan pergumulan pada saat itu, bahaya takhayul tetap meracuni ibadah masa kini. Mulai dari keyakinan akan kuasa magis dari roti dan anggur dalam Perjamuan Kudus, minyak, dan barangbarang lain yang dipercaya memiliki khasiat gaib. Ini semua menyatakan bahwa gereja masa kini masih harus bersikap kritis terhadap takhayul yang terjadi dalam ibadah.

Dosa liturgis yang terakhir yaitu pemberhalaan. Manusia tidak lagi menyembah Allah yang benar melainkan sesuatu yang lain yang menggantikan-Nya. Persoalan pada pemberhalaan adalah manusia ingin memiliki semacam ilah yang dapat dilihat, yang sepenuhnya terduga dan dapat dikuasai sesuai dengan kehendak atau keinginannya sendiri. ${ }^{32}$ Sebaliknya Allah yang sejati adalah Allah yang berdaulat yang menuntut manusia untuk sepenuhnya tunduk dan mengabdi kepada-Nya. Calvin menjelaskan bahwa kecenderungan absurd untuk membuat allah palsu dari materi yang mati adalah hal yang

${ }^{29} \mathrm{Bdk}$. Calvin, Instit. 1.11.8.

${ }^{30} \mathrm{Bdk}$. Calvin, Instit. 2.8.17.

${ }^{31} \mathrm{Bdk}$. Inventory of Relics, Corpus reformatorum 6.409; dikutip dari Carlos M.N. Eire, War Against the Idols: The Reformation of Worship from Erasmus to Calvin (Cambridge: Cambridge University Press, 1989), 211-212.

${ }^{32}$ Calvin mengajarkan bahwa asal usul berhala terletak pada keinginan manusia akan allah yang dapat diraba; bdk. Instit. 1.11.8. 
alamiah bagi manusia. ${ }^{33}$ Kecenderungan alamiah yang bertentangan dengan Kitab Suci ini memiliki potensi untuk merubah pemahaman manusia akan Allah. Terinspirasi oleh pemikiran Calvin tentang pemberhalaan, Michael J. Ovey dengan tepat menyatakan bahwa sebuah perubahan dalam cara seseorang memandang dirinya sendiri dengan segera akan mempengaruhi cara orang tersebut memandang Allah. ${ }^{34}$ Pada akhirnya, dinamika saling mempengaruhi antara pengenalan diri dan pengenalan akan Allah ini akan menguat dengan sendirinya. Sama seperti perjumpamaan dengan Allah yang sejati akan menghadirkan transformasi terusmenerus, demikian pula pemberhalaan juga akan mengubah kehidupan penyembahnya semakin lama semakin buruk. Di sini manusia tidak berada pada kondisi yang statis, melainkan kondisi yang terus diubahkan, baik itu oleh ibadah yang sejati, maupun oleh pemberhalaan. Relevansi pemikiran ini bagi ibadah masa kini adalah bahwa tanpa pemahaman yang benar akan Allah, jemaat akan masuk pada penyembahan akan allah seperti yang dikehendakinya, yang sebenarnya hanya merupakan proyeksi dari diri, seperti yang dikatakan oleh Feuerbach. ${ }^{35}$ Ibadah yang memiliki pusat pada pemenuhan keinginan diri daripada hasrat untuk melakukan kehendak Allah sebenarnya merupakan akibat dari pemberhalaan dalam ibadah.

\section{METAFORA-METAFORA IBADAH}

Di dalam pemahaman Bierma dan Witvliet, Calvin menggunakan berbagai gambar atau metafora untuk menjelaskan arti dan tujuan ibadah seperti anak tangga, pohon yang

${ }^{33}$ Calvin mengutarakan, "For surely there is nothing less fitting than to wish to reduce God, who is immeasurable and incomprehensible, to a five-foot measure! And yet custom shows this monstrous thing, which is openly hostile to the order of nature, to be natural to men" (Instit. 1.11.4).

${ }^{34}$ Bdk. Michael J. Ovey, "The Echo Chamber of Idolatry," dalam Themelios 41.2 (2016), 215.

${ }^{35}$ Bdk. Ludwig Feuerbach, Wesen des Christentums, Gesammelte Werke 5, ed. Werner Schuffenhauer dan Wolfgang Harich (Berlin: Akademie-Verlag, 1984), 46 berbuah, percakapan/komunikasi, cermin, pesta, pengorbanan, ratifikasi perjanjian, dan kesaksian. $^{36}$ Ibadah yang diberkati Tuhan mampu menghadirkan keanekaragaman aspek ini dan bukan hanya satu atau dua aspek saja. Sudah dalam penggunaan metafora dan gambar, pemikiran Calvin tentang ibadah memiliki potensi bagi ibadah masa kini yang lebih banyak diwarnai oleh gambar daripada pemahaman proposisional. Filsuf pascamodern seperti Ricoeur melihat bahasa metaforis sebagai wahana utama untuk pengungkapan bentuk-bentuk makna daripada epistemologi atau objektifikasi murni. ${ }^{37} \mathrm{Am}$ biguitas metafora justru dianggap memiliki kekuatan untuk menjelaskan kekayaan aspek atau dimensi sebuah realitas. Kebenaran dari sebuah metafora lebih merupakan masalah pengungkapan atau penyingkapan daripada urusan koherensi. Demikian kita mendapati bahwa metafora-metafora ibadah yang digunakan oleh Calvin seringkali membawa kepada ketegangan yang seolah tidak koheren, namun ketegangan ini adalah ketegangan yang kreatif. Metafora yang hidup dapat mengatakan lebih dari satu hal pada saat yang sama. Terakhir, diskursus metaforis justru berkembang dari bahasa yang sudah ada, yang kemudian dapat digunakan (dan dilampaui) oleh diskursus metaforis tersebut. Menyoroti hal ini, Calvin dengan penggunaan gambaran metaforisnya tentang ibadah dapat dikatakan mendahului para teolog yang memahami ibadah dalam pemahaman proposisional.

Metafora pertama yang digunakan Calvin adalah tangga. Menurut Maag, gambaran tangga ini merupakan salah satu gambaran favorit Calvin tentang bagaimana Allah menarik umat-Nya ke dalam pemahaman

${ }^{36}$ Bdk. Witvliet \& Bierma, "Liturgy," 417; lih. juga Witvliet, Worship Seeking Understanding, 133-145.

${ }^{37}$ Lihat Paul Ricoeur, The Rule of Metaphor: MultiDisciplinary Studies in the Creation of Meaning in Language, terj. Robert Czerny dengan Kathleen McLaughlin dan John Costello, S. J. (London: Routledge and Kegan Paul, 1986). 
iman yang lebih dalam. ${ }^{38}$ Ibadah sebagai tangga berarti ada pergerakan dari bawah ke atas yang mengarah kepada klimaks tertentu. Metafora langkah atau tangga sebenarnya telah digunakan dalam tulisan-tulisan mistik. ${ }^{39}$ Namun, perlu dicatat bahwa bagi reformator seperti Calvin, manusia tidak naik tangga dengan upaya mereka sendiri; sebaliknya, manusia dapat naik ke atas karena Kristus telah terlebih dahulu turun dari surga dan tinggal di antara umat manusia. Calvin mengaitkan perkataan Kristus tentang "malaikat-malaikat Allah" yang "turun naik kepada Anak Manusia" (Yoh. 1:51) dengan tangga yang dinyatakan Allah pada Yakub melalui mimpi (bdk. Kejadian 28:12). Bagi Calvin, ini berarti tangga, yang kepadanya malaikat-malaikat Allah turun naik itu adalah Kristus, yang melalui kedatanganNya telah membuka pintu gerbang surga. ${ }^{40}$ Demikian pula terjadi pertukaran bahagia dalam Perjamuan Kudus: Kristus yang telah turun ke bumi telah mempersiapkan jalan naik ke surga bagi jemaat. ${ }^{41}$ Jadi, naik dalam ibadah, menghampiri Allah yang ada di surga adalah respons atas undangan Allah yang penuh kasih karunia. Orang percaya tidak naik dengan kekuatan mereka sendiri; mereka naik karena Allah telah mengundang mereka untuk bersekutu dengan-Nya melalui Kristus. Aplikasi dari konsep ini bagi ibadah masa kini adalah bahwa gereja harus berhati-hati untuk tidak menciptakan suasana ibadah yang berusaha untuk diangkat ke atas dengan keahlian manusia sendiri dan bukan sebagai respons atas undangan ilahi di dalam Kristus. Natur responsif dari ibadah perlu ditekankan dalam teologi ibadah masa kini.

\footnotetext{
${ }^{38}$ Bdk. Maag, Lifting Hearts, 115.

${ }^{39}$ Bernard dari Clairvaux, misalnya, membahas dua belas langkah menuju kerendahan hati dan kecongkakan; lih. Bernard of Clairvaux, The Steps of Humility \& Pride dalam Bernard of Clairvaux: Selected Works (New York: Paulist Press, 1987). Teresa dari Avila (seorang penulis mistik yang hidup sezaman dengan Calvin) juga menulis tentang tujuh langkah dalam karyanya Puri Batin; lih. Teresa of Avila, The Interior Castle (London: Fount, 1995).

${ }^{40} \mathrm{Bdk}$. Calvin, Instit. 2.9.2.

${ }^{41}$ Bdk. Calvin, Instit. 4.17.2.
}

Gereja tidak dipanggil untuk mengusahakan tata cara ibadah yang menarik namun yang dikembangkan dari bawah. Sebaliknya, gereja perlu mengusahakan agar segala kekayaan perkataan Kristus diam di antara jemaat (bdk. Kol. 3:16), sehingga jemaat dapat merespons dengan ibadah yang naik ke atas dan diterima oleh Allah. Ibadah sebagai tangga juga memiliki aplikasi masa kini bahwa ibadah perlu memiliki klimaks. Ibadah yang tanpa klimaks akan menjadi ibadah datar yang miskin pengalaman perjumpaan dengan Allah yang hidup.

Metafora yang lain adalah pohon buah. Artinya, ibadah harus bisa dinikmati oleh mereka yang sedang beribadah. Calvin menafsirkan pohon kehidupan yang buahnya dapat memberikan hidup yang kekal (bdk. Kej. 3:22) sebagai salah satu contoh dari sakramen yang dinyatakan dalam hal-hal alami. ${ }^{42}$ Dengan kata lain, bagi Calvin, menikmati buah pohon kehidupan itu bukan hanya akan terjadi di surga dalam konteks pengharapan eskatologis, melainkan juga di sini dan sekarang khususnya ketika orang percaya berbagian dalam sakramen Perjamuan Kudus dalam ibadah. Potensi pemahaman ini bagi ibadah masa kini adalah bahwa ibadah yang diberkati adalah ibadah yang menghidangkan berbagai makanan dan minuman rohani yang lezat. Pemberitaan firman Tuhan dengan kata-kata klise, kurangnya kekayaan dari kehidupan doa dan nyanyiannyanyian rohani merupakan problem yang serius dihadapi gereja masa kini. Jemaat tidak dipuaskan dengan pelayanan rohani yang diberikan oleh gereja. Sebagian gereja malah mencari alternatif-alternatif baru bukan dari kekayaan tradisi Kristen melainkan dari tradisi kepercayaan yang lain. Ini menyatakan bahwa gambaran ibadah sebagai pohon buah yang seharusnya dapat dinikmati masih sangat relevan pada hari ini. Tugas dan panggilan para pelayan ibadah adalah melayani umat Allah dengan hidangan rohani ini. Ibadah

${ }^{42}$ Bdk. Calvin, Instit. 4.14.18. 
yang diberkati akan selalu menarik dan tidak mungkin membosankan karena senantiasa menyajikan kenikmatan rohani.

Metafora berikutnya adalah percakapan atau komunikasi. Percakapan selalu merupakan lalu lintas dua arah. Pertama, Allah berbicara kepada manusia, kemudian manusia menanggapi perkataan-Nya. Dalam tafsirannya atas Yeremia 7:22-23, Calvin mengingatkan bahwa Allah tidak dapat disembah, kecuali manusia terlebih dahulu mendengar suara-Nya; setelah manusia mendengar suaraNya, ia berespons dengan kasih yang tulus dari dalam hati. ${ }^{43}$ Allah menyatakan diri-Nya pada manusia; manusia menaruh kepercayaannya pada kebaikan-Nya, bergantung sepenuhnya pada belas kasihan-Nya, meminta pertolongan dari pada-Nya, dan mempersembahkan korban syukur bagi-Nya. Dalam pemahamannya tentang doa yang adalah percakapan antara manusia dan Allah, Calvin mengingatkan bahwa tidak ada orang yang dapat menghampiri Allah dan berdoa dengan benar kecuali mereka telah terlebih dahulu digerakkan oleh keagungan-Nya. ${ }^{44}$ Allah terlebih dahulu mengkomunikasikan atau menyatakan keagungan-Nya, baru kemudian manusia merespons dengan doa. Aplikasi pemahaman ini bagi ibadah masa kini adalah bahwa ibadah seharusnya memberi tempat bagi Allah untuk berbicara dan menyapa manusia dan bukan hanya manusia berbicara kepada Allah. Demikian pula sebaliknya, ibadah juga seharusnya merespons apa yang Allah telah nyatakan dan bukan tidak berespons atas keagungan ilahi. Gereja masa kini perlu menghindari dua ekstrem yang sama-sama keliru: di satu sisi penekanan terhadap Allah yang berbicara namun kurang adanya tempat untuk merespons dan di sisi yang lain penekanan terhadap jemaat yang berbicara kepada Allah namun tidak memberikan ruang bagi Allah berbicara.

\footnotetext{
${ }^{43}$ Tafsiran Calvin atas Yeremia 7:22-23 seperti yang dikutip Witvliet, Worship Seeking Understanding, 139.

${ }^{44}$ Bdk. Calvin, Instit. 3.20.5.
}

Berikutnya, metafora cermin. Ibadah sebagai cermin berarti ibadah akan menuntun manusia untuk mengenal diri dengan lebih baik dan lebih dalam di hadapan Allah. Pada bagian awal Institutio, Calvin menegaskan bahwa tidak ada pengenalan yang benar akan Allah yang tidak membawa dampak pada pengenalan akan diri. ${ }^{45}$ Ini berarti pengenalan akan Allah akan memperhadapkan manusia pada sebuah cermin. Pada bagian lain, Calvin menyebut fungsi pertama dari Taurat itu seperti cermin, di mana manusia melihat kelemahan dan kesalahannya. ${ }^{46} \mathrm{Di}$ sisi yang lain, Calvin juga menyebut inkarnasi Kristus sebagai cermin, yang di hadapannya manusia melihat kebaikan Allah dan kasihNya yang tak terbatas. ${ }^{47}$ Ibadah sebagai cermin berarti manusia melihat kegagalannya di hadapan tuntutan Taurat dan melihat penerimaan Allah dalam Kristus. Seperti diajarkan oleh Calvin, gereja masa kini juga perlu memahami metafora cermin ini dalam ibadahnya. Cermin berbeda dengan jendela. Jendela melihat keluar, melihat yang lain, sementara cermin melihat diri sendiri. Berjumpa dengan Allah dan firman-Nya tidak dapat dialami tanpa memperoleh pengenalan yang lebih dalam tentang diri sendiri. Firman Tuhan bukanlah sesuatu yang dilihat manusia tanpa menyadari posisinya sendiri. Ibadah sebagai cermin menciptakan sikap introspeksi diri di dalam jemaat. Ini bukan hanya tentang pengetahuan obyektif mengenai doktrin yang benar dan ortodoks. Hal ini juga tentang pengenalan diri dalam terang firman Tuhan. Konsep seperti ini akan menjadikan ibadah masa kini menjadi ibadah yang transformatif karena jemaat diundang untuk melihat diri mereka dalam terang firman.

Metafora yang lain adalah pesta. Ibadah sebagai sebuah pesta berarti ibadah harus memiliki aspek perayaan. Meskipun ada ke-

\footnotetext{
${ }^{45}$ Calvin, Instit. 1.1.1-2.

${ }^{46}$ Calvin, Instit. 2.7.7.

${ }^{47}$ Calvin, Instit. 2.12.4.
} 
khidmatan, ibadah tidak menjadi suram. Khususnya pada masa Reformasi, penting bagi para reformator untuk menekankan karakter Injil yang penuh sukacita. ${ }^{48}$ Calvin pun menekankan aspek pesta ini khususnya ketika dia membicarakan tentang Perjamuan Kudus. Mengritik kepercayaan Roma Katolik pada zamannya, Calvin menegaskan, "He has therefore given us a Table at which to feast, not an altar upon which to offer a victim; he has not consecrated priests to offer sacrifice, but ministers to distribute the sacred banquet." 49 Calvin membenturkan aspek pesta dengan pengorbanan pada bagian ini (di bawah akan dibahas bahwa aspek pengorbanan bukan tidak ada tempatnya sama sekali dalam pemikiran Calvin). Aplikasi bagi ibadah masa kini adalah bahwa Perjamuan Kudus sesungguhnya merupakan cicipan perjamuan surgawi yang akan dinikmati kelak. Konsep cicipan ini penting setidaknya untuk menyingkirkan dua pandangan yang keliru dalam ibadah masa kini: gereja yang hanya mementingkan manfaat Perjamuan Kudus di sini dan sekarang tanpa melihat perlunya pengharapan eskatologis di satu sisi, dan gereja yang hanya memiliki pengharapan eskatologis yang akan datang tanpa sanggup menghayati makna Perjamuan di sini dan sekarang di sisi lain. Metafora pesta menjamin ibadah masa kini menjadi ibadah yang menarik, penuh kejutan, dan mengundang manusia untuk merespons injil sebagai kabar baik.

Secara dialektis, metafora pesta ini tidak dapat dipisahkan dengan metafora yang lain, yaitu korban (sacrificium). Calvin menyajikan tegangan dialektis antara pesta dan korban ini dengan indah ketika dia meng-

${ }^{48}$ Luther menyamakan penemuan Injil dengan sukacita sejati, sementara perkataan Zwingli yang terkenal adalah "Kebenaran memiliki wajah bahagia" atau "Laeta est veri facies, ac minime superciliosa, sed inadulabilis simul est" yang artinya: mereka yang mengenal kebenaran yang memerdekakan akan memiliki sukacita sejati dalam hidup mereka. Lihat Huldreich Zwingli, Sämtliche Werke, vol. 3, Corpus Reformatorum 90 (Zürich: Theologischer Verlag, 1981), 820.

${ }^{49}$ Calvin, Instit. 4.18.12. gambarkan ibadah sebagai korban ucapan syukur. ${ }^{50}$ Bagi Calvin, ibadah yang memiliki gambaran korban ini tidak boleh hanya bersifat eksternal, melainkan terutama menggerakkan jemaat untuk menguduskan dan mendedikasikan diri sepenuhnya bagi Tuhan. Meskipun Calvin mengajarkan bahwa kasih dan dedikasi kepada Tuhan mendahului kasih kepada sesama, ${ }^{51}$ ada dimensi kasih dan pengorbanan bagi sesama dalam teologi ibadah Calvin. Elemen persekutuan kasih kepada sesama ini diekspresikan melalui kolekte untuk sedekah dalam liturgi yang disusun oleh Calvin..$^{52}$ Konsep seperti ini juga sangat sejalan dengan ajaran dalam Kitab Mikha bahwa ada integrasi antara ibadah yang sejati dan kepedulian sosial. Potensi konsep ini bagi ibadah masa kini adalah undangan untuk menghadirkan ibadah secara paradoks. Pesta dan korban biasanya tidak berjalan seiring. Pesta memiliki aspek perayaan, sementara korban merupakan suatu peringatan yang dihayati dengan kesedihan. Kedua aspek ini justru hadir dalam ibadah pada umumnya dan Perjamuan Kudus pada khususnya. Perjamuan Kudus adalah sekaligus pesta dan korban. Melihat ke belakang, Perjamuan Kudus adalah peringatan kematian dan pengorbanan Kristus, yang mencurahkan darah-Nya di kayu salib untuk menebus umat manusia dari dosa. Perjamuan Kudus dengan indah mengakomodasi ketegangan kreatif antara pesta dan pengorbanan, antara sukacita dan dukacita. Tentu saja, dari perspektif teologi reformatoris, Perjamuan $\mathrm{Ku}-$ dus bukanlah pengorbanan yang manusia persembahkan kepada Allah, melainkan, Kristus adalah Sang Korban yang diberikan oleh Bapa bagi penebusan umat pilihan.

${ }^{50}$ Bdk. Calvin, Instit. 4.18.16; tentang bagian Institutes ini Witvliet mengomentari: "Worship is a sacrifice but a sacrifice of praise and not propitiation" (Witvliet, Worship Seeking Understanding, 142).

${ }^{51}$ Bdk. tafsiran Calvin terhadap Mikha 6:6-8 dalam Calvin: Commentaries, 316.

${ }^{52} \mathrm{Bdk}$. Elsie Anne McKee, "Reformed Worship in the Sixteenth Century," dalam Christian Worship in Reformed Churches Past and Present, ed. Lukas Vischer (Grand Rapids: Eerdmans, 2003), 23-24. 
Namun, umat Allah juga berespons dengan mengorbankan diri kepada-Nya sebagai korban yang hidup..$^{53}$ Mempersembahkan diri kepada Allah sebagai korban yang hidup merupakan fungsi keimaman seorang Kristen. Ibadah masa kini seharusnya mengingatkan orang percaya akan pengorbanan Kristus dan pada saat yang sama mendorong orang percaya untuk merespons dengan mempersembahkan diri kepada Allah dengan menjalani kehidupan yang berkorban bagi Allah.

Metafora yang lain yang digunakan Calvin yaitu ratifikasi perjanjian. Sekali lagi mengambil sakramen sebagai salah satu elemen yang terpenting dalam ibadah, Calvin menyebut bahwa sakramen bagi manusia adalah hal yang sama seperti jaminan ratifikasi perjanjian. ${ }^{54}$ Tentang darah perjanjian dalam Ibrani 9:20, Calvin mengo-mentari, "This means that the testament is not ratified without blood, and that the blood works no expiation without the testament. Therefore, the two must go together." 55 Perjanjian diratifikasi oleh darah yang melambangkan pengampunan dosa, sementara pengampunan dosa membawa kepada ikatan perjanjian. Apakah potensi konsep ratifikasi perjanjian ini bagi ibadah masa kini? Ibadah sebagai ratifikasi perjanjian memiliki arti, pertama, menyatakan fakta kebenaran bahwa manusia adalah pelanggar perjanjian. Umat Allah tidak hidup sebagai-mana seharusnya di hadapan Allah, yaitu sebagai pemelihara perjanjian. Sebagai pelanggar perjanjian, jemaat perlu diingatkan berulang kali bahwa Allah adalah Allah yang setia. Dia tetap setia sekalipun umat-Nya tidak setia. Ibadah masa kini perlu menyatakan dengan jelas apa yang diajarkan dalam Kitab Imamat, yaitu berita pengampunan dosa. Jemaat diundang lagi untuk menjadi umat milik Tuhan, yang menjadikan

\footnotetext{
${ }^{53}$ Konsep ini dengan indah dinyatakan dalam pertanyaan ke-32 Katekismus Heidelberg.

${ }^{54}$ Calvin, Instit. 4.14.17.

${ }^{55}$ Tafsiran Calvin terhadap Ibrani 9:20 dalam Calvin: Commentaries, 101.
}

Tuhan sebagai satu-satunya Tuhan. Tanpa berita pengampunan, khotbah Reformed dapat memiliki kecenderungan menghadirkan gerakan kehidupan yang lebih tinggi (higher life movement), sebuah gerakan yang berupaya untuk menggapai kesempurnaan kekudusan Kristen, namun dengan sedikit atau kurang penekanan pada kasih karunia dan belas kasihan ilahi. Gerakan ini seringkali menciptakan kekristenan legalistik yang lebih bersifat menekan daripada membebaskan karena kedekatannya dengan ajaran perfeksionisme. ${ }^{56}$ Di sisi lain, metafora ratifikasi perjanjian juga mencegah pemahaman tentang kasih karunia yang murahan, yaitu, tawaran pengampunan dosa tanpa undangan masuk dalam kehidupan baru sebagai pemelihara perjanjian. Jadi, ratifikasi perjanjian berarti pengampunan dosa dan pemulihan hidup dalam perjanjian dengan Allah: hidup orang percaya bukan milik sendiri melainkan milik Tuhan. Ibadah masa kini seharusnya membawa jemaat untuk menyadari penerimaan ilahi dalam pengampunan-Nya sekaligus kesadaran untuk hidup yang terusmenerus diperbaharui sebagai umat perjanjian.

Akhirnya, Calvin juga menggunakan metafora kesaksian atau saksi bagi ibadah. Bagi Calvin, agama yang sejati ditandai dengan keberanian menyaksikan nama Tuhan di hadapan manusia. ${ }^{57}$ Dalam suratnya kepada para wanita yang ditahan di penjara di Paris, Calvin menghibur mereka dengan mengatakan bahwa tidak ada khotbah yang seefektif keberanian dan ketekunan yang dimiliki oleh

${ }^{56}$ B.B. Warfield telah melakukan kritik terhadap gerakan ini dalam artikelnya "The Higher Life Movement". Lihat Benjamin B. Warfield, Studies in Perfectionism, The Works of Warfield, vol. 7 dan 8 (Grand Rapids: Baker Books, 2003).

${ }^{57}$ Dalam tafsirannya terhadap Matius 10:32, Calvin mengatakan, "In other words, he [Christ] intends that the profession of his name shall be set in opposition to false religions: and as it is a revolting matter, he enjoins the testimony which we must bear, that the faith of each person may not remain concealed in the heart, but may be openly professed before men." 
para martir dalam menyaksikan nama Kristus. ${ }^{58}$ Potensi metafora kesaksian bagi ibadah masa kini adalah pentingnya kaitan gereja yang hidup dan kuasa kesaksian. Kebangunan rohani seringkali ditandai dengan keberanian untuk mengakui Kristus dalam ibadah, sebuah pengakuan iman yang bertentangan dengan dunia yang membenci Kristus. Dalam Injil Yohanes, para murid Kristus disebut saksi. Latar kehidupan (Sitz im Leben) dari saksi adalah di ruang pengadilan. Di pengadilan ada hakim, jaksa, terdakwa, pembela, dan saksi. Ibadah sebagai kesaksian akan membawa jemaat sadar bahwa posisi Tuhan di dunia berada pada posisi terdakwa. Dunia dalam posisi penuntut, membawa kasus hukum bahwa Yesus adalah pembohong, penghujat agama, dan pemberontak. Gereja masa kini dipanggil untuk menjadi saksi bagi Yesus yang didakwa. Ibadah harus memiliki sifat pengakuan (confessio), yaitu, memiliki keberanian untuk mengakui posisi orang percaya di hadapan Allah dan di hadapan dunia. Salah satu contoh yang indah dari pemahaman metafora kesaksian ini dapat kita jumpai dalam masa kekejaman rezim Nazi di Jerman, di mana gereja-gereja diminta untuk tunduk pada pemerintahan Hitler, yang menyebut dirinya der Führer (Pemimpin). Banyak gereja yang menyerah pada ideologi politik ini. Namun, ada sekelompok kecil orang Kristen yang tergabung dalam kelompok yang disebut Confessing Church menuliskan deklarasi teologis yang disebut Deklarasi Barmen pada tahun 1934. Deklarasi ini menentang pemerintahan gereja yang korup yang tunduk pada ideologi Nazi. Tesis pertama berbunyi:

Yesus Kristus, sebagaimana dia disaksikan dalam Kitab Suci, adalah satu-satunya Firman Allah yang harus kita dengar, kita percayai, dan kita taati baik dalam hidup

${ }^{58}$ Lihat John Calvin, "Letter to the Women Detained in Prison at PARIS, 16 Sept. 1557," dalam John Calvin: Writings on Pastoral Piety, ed. Elsie Anne McKee (New York: Paulist Press, 2001), 332. maupun mati. Kami menolak doktrin palsu bahwa gereja dapat dan harus mengakui peristiwa dan kekuatan lain, tokoh dan kebenaran sebagai wahyu Allah sebagai sumber pemberitaannya di luar dan selain dari satu firman Allah ini. ${ }^{59}$

Pernyataan pengakuan dan polemik semacam itu merupakan aplikasi konkret dari gambaran gereja yang bersaksi. Gereja tidak dipanggil untuk benar secara politis lebih daripada benar secara teologis. Ketika Tuhan menghidupkan kembali gereja-Nya, keberanian untuk mengakui Kristus dalam ibadah, sebuah pengakuan yang bertentangan dengan dunia yang membenci Kristus, pasti akan terlihat. Gereja dipanggil untuk menjadi gereja yang bersaksi.

\section{KESIMPULAN}

Dari pembahasan artikel ini dapat disimpulkan bahwa pemikiran Calvin tentang ibadah masih sangat relevan untuk dikontekstualisasikan dalam zaman kita. Pandangan Calvin tentang ibadah bukan hanya seputar perdebatan tentang penggunaan alat musik dan nyanyian Mazmur, melainkan juga menawarkan potensi yang kaya dalam mengaplikasikan prinsip-prinsip dasar teologi reformatoris dalam aspek ibadah, kesulitankesulitan atau bahaya-bahaya dalam ibadah yang dapat diantisipasi, dan juga kekayaan gambaran atau metafora tentang ibadah.

Kekayaan pemikiran Calvin pada akhirnya menunjuk pada kekayaan Kitab Suci dan karena itu memiliki potensi relevansi yang

${ }^{59}$ Deklarasi Barmen ini sebagian besar ditulis oleh Karl Barth yang sangat dipengaruhi oleh pemikiran Calvin. Dalam bahasa aslinya berbunyi, "Jesus Christus, wie er uns in der Heiligen Schrift bezeugt wird, ist das eine Wort Gottes, das wir zu hören, dem wir im Leben und im Sterben zu vertrauen und zu gehorchen haben. Wir verwerfen die falsche Lehre, als könne und müsse die Kirche als Quelle ihrer Verkündigung außer und neben diesem einen Worte Gottes auch noch andere Ereignisse und Mächte, Gestalten und Wahrheiten als Gottes Offenbarung anerkennen," lih. https:// www.ekd.de/Barmer-Theologische-Erklarung-Thesen11296.htm, diakses 6 November 2020. 
langgeng. Pemikiran-pemikiran Calvin mengenai ibadah sebenarnya bersifat sporadis, kompleks, dan tidak linear. Mulai dari penekanan komprehensif reformasi total daripada sekedar khotbah, kesederhanaan ibadah yang mengajak gereja masa kini untuk memikirkan ulang apa yang sungguh-sungguh esensial dalam ibadah, pemahaman tentang ibadah surgawi yang dapat menolong gereja masa kini untuk membebaskan diri dari paham naturalisme, dan pemahaman tentang agama yang sejati yang menolong gereja masa kini untuk menghayati baik transendensi maupun imanensi ilahi, pemikiran Calvin masih berbicara secara kontekstual pada saat ini.

Demikian pula pandangan Calvin tentang dosa-dosa liturgis dapat menolong gereja masa kini untuk senantiasa mengantisipasi dan mewaspadai kerusakan-kerusakan yang dapat ditimbulkan melaluinya. Baik itu dosa ketidaktaatan, kemunafikan, takhayul, maupun pemberhalaan masih merupakan musuh terbesar bagi ibadah masa kini. Calvin tidak hanya menyediakan perspektif negatif tentang bahaya-bahaya dalam ibadah, melainkan ia juga menyediakan penangkalnya. Perspektif kritis seperti ini penting bagi gereja masa kini agar tidak jatuh dalam euforia yang disalahmengerti sebagai ibadah yang hidup dan berkenan pada Allah.

Pada akhirnya, penggunaan bahasa metaforis untuk menggambarkan ibadah membawa Calvin pada pemikir yang seolah sudah mengantisipasi zaman pascamodern yang mengeksplorasi diskursus metaforis lebih daripada proposisi-proposisi logis yang menuntut koherensi. Sama seperti halnya dengan metafora, gambaran-gambaran ibadah yang dipergunakan Calvin tidak jarang menghadirkan ketegangan. Namun ini bukanlah ketegangan kontradiktif atau tidak koheren melainkan ketegangan kreatif. Gambaran yang multifaset ini diharapkan dapat menolong gereja masa kini untuk menghadapi monotoni ibadah di satu sisi dan diversitas liar yang tanpa struktur di sisi yang lain.

\section{DAFTAR KEPUSTAKAAN}

Barth, Karl. Theology of John Calvin. Diterjemahkan oleh Geoffrey W. Bromiley. Grand Rapids: Eerdmans, 1995.

Begbie, Jeremy. Music, Modernity, and God. Oxford: Oxford University Press, 2014.

Bernard of Clairvaux. Bernard of Clairvaux: Selected Works. Diterjemahkan oleh G.R. Evans. New York: Paulist Press, 1987.

Calvin, Jean. Ioannis Calvini Tractatus theologici minores. Dalam Ioannis Calvini opera quae supersunt omnia. Vol. 6. Corpus Reformatorum 34. Brunsvigae: Schwetschke, 1867.

Calvin, John. Calvin's Commentaries: The Harmony of the Gospels. Logos Library System.

Software.

Calvin's Commentaries: Romans. Ages

- Calvin: Commentaries. Diedit oleh J. Haroutunian dan L.P. Smith. Philadelphia: Westminster Press, 1958.

. Institutes of the Christian Religion. 1536.

Diterjemahkan oleh Ford L. Battles. Reprint, Grand Rapids: Eerdmans, 1995. . Institutes of the Christian Religion. 2 vol. Diedit oleh John T. McNeill. Diterjemahkan oleh Ford L. Battles. Philadelphia: Westminster, 1959.

. John Calvin: Writings on Pastoral Piety. Diedit oleh Elsie Anne McKee. New York: Paulist Press, 2001.

. Selections from His Writings. Diedit oleh

J. Dillenberger. Garden City: Doubleday, 1971.

. "Short Treatise on the Holy Supper of Our Lord and Only Saviour Jesus Christ." Dalam Calvin: Theological Treatises. Diterjemahkan dan diedit oleh J.K.S. Reid. Library of Christian Classics Vol. 22. Philadelphia: Westminster Press, 1965.

Cypris, Ottoman Frederick. "Basic Principles: Translation and Commentary of Martin Bucer's Grund und Ursach, 1524." Disertasi, Union Theological Seminary, 1971.

Dilthey, Wilhelm. Die Glaubenslehre der Reformatoren. Preuss. Jahrb. 1894. 
Eire, Carlos M.N. War Against the Idols: The Reformation of Worship from Erasmus to Calvin. Cambridge: Cambridge University Press, 1989.

Feuerbach, Ludwig. Wesen des Christentums. Gesammelte Werke 5. Diedit oleh Werner Schuffenhauer dan Wolfgang Harich. Berlin: Akademie-Verlag, 1984.

Frame, John. "Some Questions about the Regulative Principle." Westminster Theological Journal 54, no. 2 (1992): 357-66.

Godfrey, Robert. "John Calvin's View on Worship." Banner of Truth. Diakses 8 Januari 2020. https://banneroftruth.org/ us/resources/articles/2003/john-calvinsviews-on-worship.

Grandjean, Michel. "Genf: Johannes Calvin und Theodor Beza." Dalam Europa reformata. Reformationsstädte Europas und ihre Reformatoren. Diedit oleh Michael Welker, Michael Beintker dan Albert de Lange, 147-156. Leipzig: Evangelische Verlagsanstalt, 2016.

Hare, D.R.A. Matthew. Interpretation, a Bible Commentary for Teaching and Preaching. Louisville: John Knox, 1993.

Luther, Martin. "Invocavit Sermon 2 (March 1522)." Diterjemahkan oleh John Doberstein. Dalam Documents from the History of Lutheranism, 1517-1750. Diedit oleh Eric Lund. Minneapolis: Fortress, 2002.

Maag, Karin. Lifting Hearts to the Lord: Worship with John Calvin in SixteenthCentury Geneva. Grand Rapids: Eerdmans, 2016.

Maxwell, William D. An Outline of Christian Worship: Its Development and Forms. London: Oxford University Press, 1965.

McKee, Elsie Anne. "Context, Contours, Contents: Towards a Description of the Classical Reformed Teaching on Worship." Dalam Princeton Seminary Bulletin 16 (1995): 172-201.

. "Reformed Worship in the Sixteenth Century." Dalam Christian Worship in Reformed Churches Past and Present. Diedit oleh Lukas Vischer. Grand Rapids: Eerdmans, 2003.
Old, Hughes Oliphant. Worship: Reformed according to Scripture. Louisville: Westminster John Knox, 2002.

Ovey, Michael J. "The Echo Chamber of Idolatry." Themelios 41, no. 2 (2016): 214 216.

Ricoeur, Paul. The Rule of Metaphor: MultiDisciplinary Studies in the Creation of Meaning in Language. Diterjemahkan oleh Robert Czerny, Kathleen McLaughlin dan John Costello. London: Routledge and Kegan Paul, 1986.

Schwertley, Brian M., Stephen Pribble dan John Frame. Sola Scriptura and the Regulative Principle of Worship. Southfield: Reformed Witness, 2000.

Warfield, Benjamin B. Studies in Perfectionism. The Works of Warfield. Vol. 7 dan 8. Grand Rapids: Baker Books, 2003.

Webber, Robert. "Blended Worship." Dalam Exploring the Worship Spectrum. Diedit oleh Paul A. Basden. Grand Rapids: Zondervan, 2010.

Witvliet, John D. dan Nathan Bierma. "Liturgy." Dalam The Calvin Handbook. Diedit oleh Herman J. Selderhuis. Grand Rapids: Eerdmans, 2009. Worship Seeking Understanding: Windows into Christian Practice. Grand Rapids: Baker Academic, 2003.

Zwingli, Huldreich. Sämtliche Werke. Vol. 3. Corpus Reformatorum 90. Zürich: Theologischer Verlag, 1981. 
